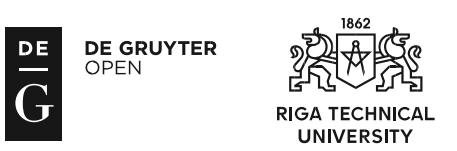

\title{
HAVE PUBLIC FINANCES IN THE OECD AREA BEEN SUSTAINABLE?
}

\author{
Ricardo FERRAZ \\ Lisbon School of Economics \& Management, University of Lisbon (ISEG), \\ Lisbon, Portugal \\ Corresponding author'se-mail:ferraz@ghes.iseg.ulisboa.pt
}

\begin{abstract}
The aim of this article is to test, from an empirical standpoint, the existence of sustainable public finances in the Organisation for Economic Cooperation and Development (OECD) area as a whole, over the most recent period of the world economy, 1973-2016. The research methods include not only standard stationarity tests, but also tests, which allow for a structural break. The relevant results of this research are a stationary public budget balance expressed as a percentage of GDP and a debt to GDP ratio that is stationary in first differences. According to the literature, this means that a "necessary and sufficient" condition is fulfilled for proving the existence of a strong sustainability. We hope this research can make a valuable contribution to the debate regarding public finances in the world economy. To obtain other relevant conclusions, additional tests will need to be performed in the future in order to assess which members are contributing to the fiscal sustainability of the OECD aggregate.
\end{abstract}

Keywords: Organisation for economic co-operation and development (OECD) area, public debt, public budget, sustainable public finances.

JEL Classification: E60, H60.

\section{INTRODUCTION}

In the theoretical literature, it is possible to find a number of similar definitions for sustainable public finances / fiscal policy sustainability. These definitions are founded on the premise of the government's solvency.

According to Blanchard et al. (1990), a sustainable fiscal policy can be defined as a policy that makes the ratio of debt eventually converge back to its initial level. On the other hand, as pointed out by Chalk and Hemming (2000), it requires that today's debt should be matched by an excess of future primary surpluses over primary deficits at current values. Adopting a similar position, the European Central Bank (2011) defined fiscal sustainability as the government's capacity to service its debt obligations in the long term, which means that a government that has outstanding debt therefore has to produce primary surpluses in the future, and these have to be large enough to accommodate the cost of servicing the government's debt obligations.

European Commission (2016) also stated that the sustainability of public finances, sometimes referred to as fiscal sustainability, is the ability of a government to sustain its policies in the long run without threatening the 
government's solvency or without defaulting. Therefore, a fiscal policy can be considered as unsustainable if, over time, it leads the government away from solvency.

Based on this concept of sustainability - associated with the government's solvency - some academic studies have been conducted with the aim of testing the sustainability of public finances / sustainability of fiscal policy in many different countries. However, it was not possible to identify any study that so far has analysed the sustainability of finances in the Organisation for Economic Cooperation and Development (OECD) area as a whole; meaning all the thirty-five member countries assessed as if they were one body.

Assessing the sustainability of this economic aggregate is an interesting issue, since it is composed of many different realities presented in more than one continent, which have been subjected to various shocks over the last decades. Taking this into account, the main aim of this article is to test the existence of sustainable public finances in the OECD over the most recent period of the world economy ${ }^{1}$; starting in 1973 , and ending in 2016. This is a relatively broad time horizon - slightly over four decades - for which comparable data relating to the public finances are available.

After the present introduction, Section 1.1 provides a brief analysis of the data. This is followed by Section 1.2, in which a framework for the empirical approach is presented. In Section 2, the sustainability of the OECD economy is tested and the results are analysed. Finally, the conclusions are documented.

\section{METHODS AND PROCEDURES}

\subsection{The Public Finances Data: Brief Analysis}

Official statistics of public finances for a relatively long time horizon, and for different nations and economic aggregates (for example, the OECD area or the euro area), is available in the OECD databases. Based on those statistics, it is possible, first of all, to analyse the evolution of the OECD area public revenue and expenditure as a percentage of GDP.

Thus, through a close observation of Figure 1, it is possible to highlight some relevant facts with regard to the behaviour of these two variables during the most recent period in the world economy, 1973-2016.

First of all, it can be seen that, despite various oscillations, public revenue and expenditure (\% of GDP) as a whole showed a slight tendency to increase in the period under analysis.

Secondly, it can be seen that there were sharp increases in public expenditure in the following sub-periods: 1974-1975, 1980-1982, 1991-1992 and 2008-2009, which were not accompanied by increases in revenue of a similar size.

\footnotetext{
${ }^{1}$ We must draw attention to Angus Maddison's periodisation for the development of the world economy: 1) 1820-1870; 2) 1870-1913; 3) 1913-1950 (“Belle Époque”); 4) 1950-1973 (“Golden Age"); 5) 1973 to present. About this topic, see, for example, Maddison (1995, 2001). The aim of this paper is precisely to test the sustainability of public finances over Period 5.
} 


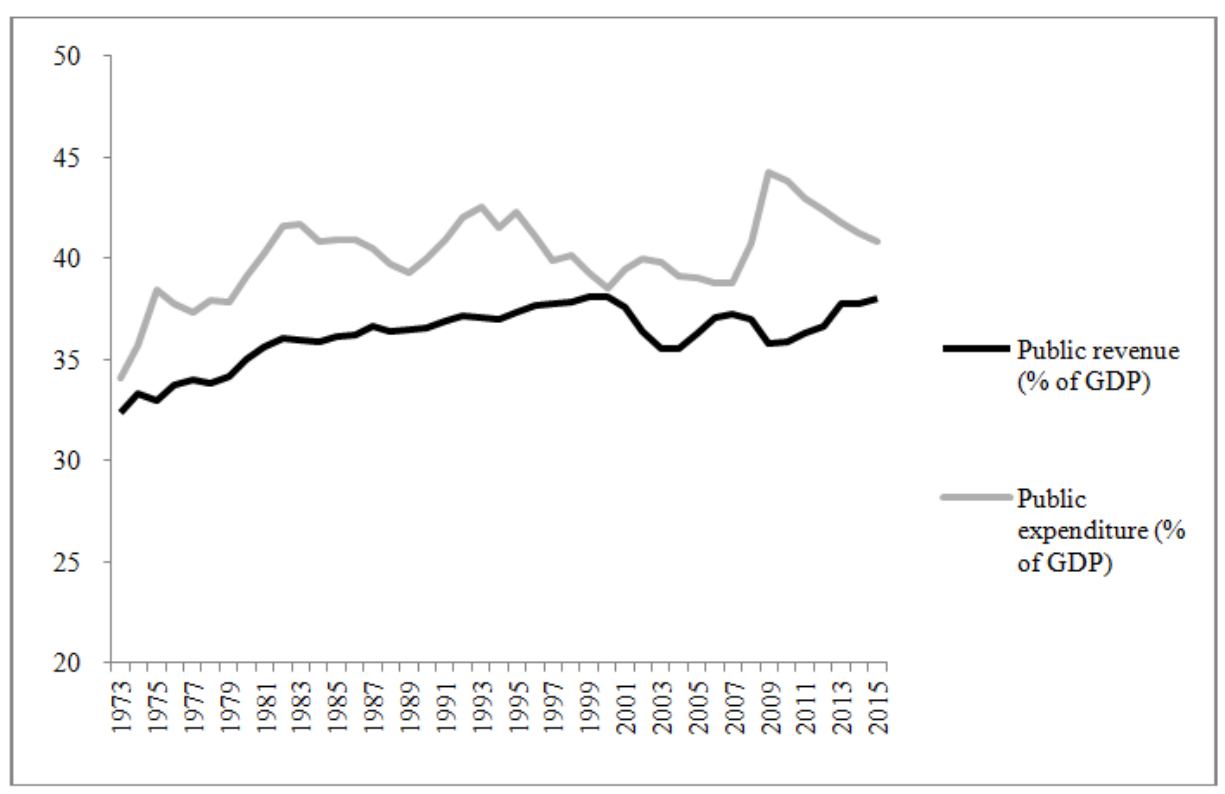

Fig. 1. OECD area public revenue and expenditure (\% of GDP), 1973-2016. (OECD, 2017).

As far as the first two sub-periods of increases are concerned, in Table 1, we present the value of public expenditure (\% of GDP) in a sample of some OECD countries for the years 1973, 1976, 1979 and 1982.

Table 1. Public expenditure (\% of GDP) in twelve OECD member countries, 1973-1982 (OECD, 2017).

\begin{tabular}{|l|r|r|r|r|r|}
\hline & \multicolumn{1}{|c|}{$\mathbf{1 9 7 3}$} & \multicolumn{1}{c|}{$\mathbf{1 9 7 6}$} & \multicolumn{1}{c|}{$\mathbf{1 9 7 9}$} & \multicolumn{1}{c|}{$\mathbf{1 9 8 2}$} & \multicolumn{2}{c|}{$\begin{array}{c}\text { Change: } \\
\text { 1982-1973 } \\
\text { (pp) }\end{array}$} \\
\hline Austria & 41.6 & 47.9 & 49.5 & 51.5 & 9.9 \\
\hline Belgium & 46.4 & 51.8 & 57.4 & 61.1 & 14.7 \\
\hline Canada & 36.0 & 39.9 & 39.6 & 46.6 & 10.6 \\
\hline Denmark & 39.9 & 45.6 & 49.8 & 56.9 & 17.0 \\
\hline Finland & 32.2 & 40.2 & 40.3 & 42.9 & 10.7 \\
\hline Italy & 35.0 & 37.7 & 39.7 & 46.0 & 11.0 \\
\hline Japan & 25.0 & 29.6 & 32.3 & 33.6 & 8.6 \\
\hline Netherlands & 43.3 & 49.5 & 51.9 & 57.0 & 13.7 \\
\hline Spain & 24.6 & 27.6 & 32.1 & 38.9 & 14.3 \\
\hline Sweden & 42.8 & 47.3 & 55.1 & 60.2 & 17.4 \\
\hline United Kingdom & 39.5 & 44.9 & 40.2 & 43.4 & 3.9 \\
\hline United States & 33.2 & 35.3 & 33.4 & 37.7 & 4.5 \\
\hline
\end{tabular}


In table 1, it can be seen that there were significant increases; in some of the countries, there were increases of more than 10 percentage points (pp). These years correspond to the disturbances related to high oil prices / oil shocks (BP, 2016).

The 1970s and the early 1980s are in fact considered in the relevant literature as turbulent times characterised by economic adversity (Llewellyn, 1983; Black, 1985).

On the other hand, in the third sub-period (1991-1992), most of the OECD countries that are considered in Table 1 displayed a more moderate increase in public expenditure (\% of GDP $)^{2}$. However, Finland and Sweden were exceptions. In these two countries, the public expenditure ratio rose from 47.9 and 56.5 of GDP in 1990 to 61.7 and 66.9, respectively, in 1992. Such changes represent significant increases in a relatively short time.

The beginning of the 1990s is in fact connoted, in the international context, with economic depression in the so-called "economic twins". Between 1990 and 1993, Finland and Sweden's GDP fell in real terms by $3.4 \%$ and $1.5 \%$ per year, respectively (the author's own calculations, using the data taken from the World Bank, 2017). Some authors attribute this crisis to the financial deregulation that occurred in the mid-1980s (Jonung, Kiander \& Vartia, 2008; Chabert \& Clavel, 2012)

Finally, the last most obvious increase in the OECD area public expenditure was in 2008-2009 (see Figure 1). These were the years that marked the intensification of the global financial crisis (European Commission, 2009) and to avoid a more prolonged recession, one of the main remedies adopted was expansionary measures (European Commission, 2008).

In Table 2, we present a new sample of public expenditure in the OECD countries, where it can be seen that in this short period of time, there were significant increases.

Table 2. Public expenditure (\% of GDP) in twelve OECD member countries, 2007 and 2009 (OECD, 2017).

\begin{tabular}{|l|r|r|r|}
\hline & \multicolumn{1}{|c|}{$\mathbf{2 0 0 7}$} & \multicolumn{1}{c|}{$\mathbf{2 0 0 9}$} & \multicolumn{1}{c|}{ Change: 2007-2009 (pp) } \\
\hline Austria & 49.5 & 54.5 & 5.0 \\
\hline Belgium & 48.2 & 54.1 & 5.9 \\
\hline Finland & 46.8 & 54.8 & 8.0 \\
\hline France & 52.2 & 56.8 & 4.5 \\
\hline Germany & 42.8 & 47.6 & 4.9 \\
\hline Greece & 47.1 & 54.1 & 7.0 \\
\hline Ireland & 35.8 & 47.1 & 11.3 \\
\hline Japan & 34.6 & 40.2 & 5.7 \\
\hline Portugal & 44.5 & 50.2 & 5.7 \\
\hline Spain & 39.0 & 45.8 & 6.8 \\
\hline United Kingdom & 41.5 & 48.6 & 7.1 \\
\hline United States & 37.2 & 43.2 & 6.0 \\
\hline
\end{tabular}

\footnotetext{
${ }^{2}$ Conclusions obtained using the same data as those that were used to construct Table 1.
} 
It is also important to stress that for the entire period of 1973-2016, the OECD area public revenue was always lower than expenditure (see again Figure 1). Consequently, there was not a single positive balance in its public accounts during the entire time horizon. However, it should be noted that the sub-period 2008-2012 stands out because of the higher deficits recorded as a percentage of GDP, as shown in Figure 2.

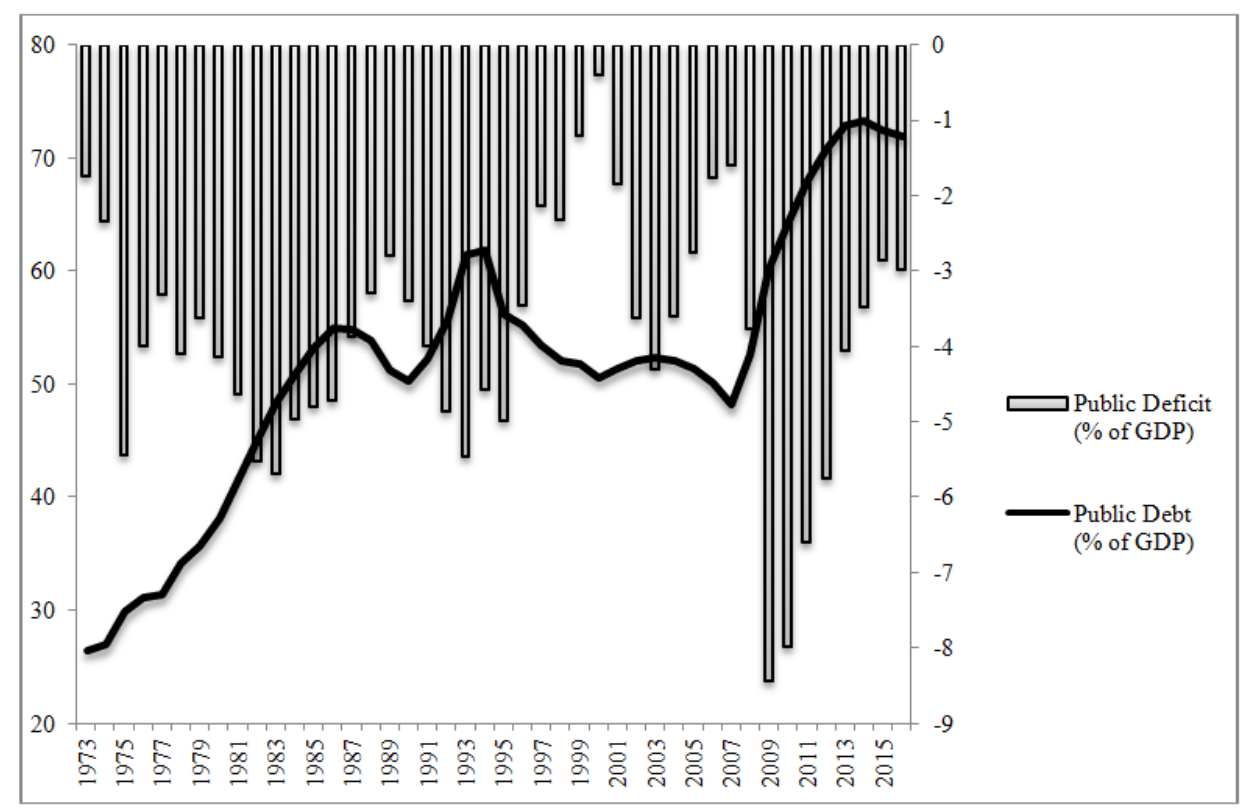

Fig. 2. OECD area public deficit and public debt (\% of GDP), 1973-2016 (OECD, 2017; AMECO, 2017; IMF, 2017).

Note 1: the OECD public deficits (\% of GDP) were obtained from the difference between the public revenue (\% of GDP) and the public expenditure (\% of GDP) presented in OECD (2017).

Note 2: the OECD public debt (\% of GDP) was calculated by the author, using the data from AMECO (2017) and IMF (2017). For more details, see Table A1 in the Appendix.

Consequently, this meant a sharp rise in the debt ratio in those same years ${ }^{3}$, a period which covers the time of the global financial crisis and the euro area sovereign debt crisis (one of the effects produced by the 2008 crisis).

In general, it is also possible to conclude that, despite several oscillations, the OECD area public debt ratio showed a clear tendency to increase when one considers the period as a whole. This trend meant an increase of forty-five percentage points (pp) when comparing the value recorded in 1973 with the one recorded in 2016.

\footnotetext{
${ }^{3}$ As far as the revenue, expenditure and respective balances for the OECD area are concerned, the data are already available (see OECD, 2017). However, in the case of the OECD area public debt, we were not able to identify any available long time series. Thus, by using both official and comparable data, we calculated an approximation for the OECD area debt ratio, based on the average of the debts of the OECD countries. For more details regarding the time horizons and sources used, see Table A1 in the Appendix.
} 
But does this evolution mean that the OECD area public finances were unsustainable during the most recent period of the world economy, 1973-2016? How can we obtain an answer to this question based on the data that we have just briefly analysed?

\subsection{Empirical Approach: Public Finances Sustainability}

It is possible to present the concept of sustainable public finances - based on the idea of the government's solvency - from an algebraic standpoint. To do so, we need to resort to the government's budget constraint, which can be displayed in real terms, as follows ${ }^{4}$ :

$$
B_{t}-B_{t-1}=r_{t} B_{t-1}+G_{t}-R_{t}
$$

where ${ }^{5}$

$G_{t}$ - the primary expenditure (expenditure without interest) at time $t$;

$R_{t}-$ the revenue at time $t$;

$r_{t}$ - the real interest rate in period $t$ paid to public debt holders;

$B_{t}$ and $B_{t-1}-$ the public debt in period $t$ and in period $t-1$.

The above equation can also be expressed as follows:

$$
B_{t}=\left(1+r_{t}\right) B_{t-1}+G_{t}-R_{t}
$$

By making a set of algebraic transformations, it is possible to deduce the government's budget constraint for successive periods, resulting in the so-called intertemporal budget constraint. Assuming that the real interest rate is stationary $(r)$, and making some changes, we will have:

$$
G_{t}+\left(1+r_{t}\right) B_{t-1}-r B_{t-1}=R_{t}+B_{t}-r B_{t-1}
$$

Considering $E_{t}$ as the primary expenditure in period $t$ plus the real interest payments (with interest rates around $r$ ), we have:

$$
\begin{aligned}
& E_{t}=G_{t}+\left(r_{t}-r\right) B_{t-1} \\
& \Leftrightarrow E_{t}+(1+r) B_{t-1}=R_{t}+B_{t} .
\end{aligned}
$$

From the last equation, and proceeding to a set of successive recursive substitutions, we can obtain the designated intertemporal budget constraint:

\footnotetext{
${ }^{4}$ For a more detailed algebraic development, see, for example, Pereira et al. (2005).

5 There are other factors not included in the equation, which may cause variations in the public debt. For the sake of simplifying the algebraic process, these factors are usually considered to be zero (see, for example, European Central Bank, 2011).
} 


$$
B_{t-1}=\sum_{S=0}^{\infty} \frac{1}{(1+r)^{S+1}}\left(R_{t+S}-E_{t+S}\right)+\lim _{S \rightarrow \infty} \frac{B_{t+S}}{(1+r)^{S+1}}
$$

A sustainable fiscal policy would therefore require the following condition:

$$
\lim _{S \rightarrow \infty} \frac{B_{t+S}}{(1+r)^{S+1}}=0
$$

Thus, a sustainable fiscal policy should ensure that the value of the public debt tends towards zero. In other words, the public debt cannot continue to grow indefinitely at a higher rate than the real interest rate.

In addition, this means that the government must have future real primary balances that have a value equal to the real debt stock in the initial period:

$$
B_{t-1}=\sum_{S=0}^{\infty} \frac{1}{(1+r)^{S+1}}\left(R_{t+S}-E_{t+S}\right)
$$

There are some empirical procedures that make it possible to validate these conditions. One of these procedures is associated with Trehan and Walsh (1991). This procedure requires that the stationarity of public debt should be tested: if the public debt is a stationary series in levels, $\mathrm{I}(0)$, or, in first differences, $\mathrm{I}(1)$, then the condition given by equation (7) will be respected. The latter case is conceptually equivalent to having a stationary public budget balance.

Thus, Trehan and Walsh (1991) considered that, in a context in which the expected real rate of interest is constant, the stationarity of the public budget balance, $\mathrm{I}(0)$, is a necessary and sufficient condition for a sustainable fiscal policy when the public debt is I(1).

Another procedure is attributed to Hakkio and Rush (1991) and involves testing public revenue and expenditure. Given that the intertemporal budget constraint can also be written for the variables in first differences, we have:

$$
\Delta B_{t}=\sum_{S=0}^{\infty} \frac{1}{(1+r)^{S-1}}\left(\Delta R_{t+S}-\Delta E_{t+S}\right)+\lim _{S \rightarrow \infty} \frac{B_{t+S}}{(1+r)^{S+1}}
$$

Considering that $\Delta B_{t}=G G_{t}-R_{t}$, after applying the no-Ponzi scheme, we will have the alternative equation (10):

$$
G G_{t}-R_{t}=\sum_{S=0}^{\infty} \frac{1}{(1+r)^{S+1}}\left(\Delta R_{t+S}-\Delta E_{t+S}\right) .
$$

Assuming that $R$ and $E$ are non-stationary variables, but that their first differences are stationary, the left side of the equation will also have to be stationary. Thus, the procedure proposed by Hakkio and Rush (1991) assumes that $G G$ and $R$ are both I(1) and involves testing the cointegration between them. This means testing the regression, $R_{t}=\alpha+\beta \cdot G G_{t}+u_{t}$, with the following two options: 1) the null hypothesis, $G G_{t}$ and $R_{t}$, both integrated of order $1, \mathrm{I}(1)$, are not cointegrated, and 2) the alternative hypothesis, $G G_{t}$ and $R_{t}$, both integrated of order 
1, I(1), are cointegrated. Note that these authors considered it more appropriate to use ratios for growing economies when testing the variables.

According to Hakkio and Rush (1991), it is a necessary condition for the sustainability of fiscal policy that $G G$ and $R$ should be cointegrated. This is also conceptually equivalent to having a stationary public budget balance.

In summary, according to the literature quoted here, the "necessary and sufficient" conditions for sustainable public finances / sustainable fiscal policy requires a stationary public debt (or a first difference stationary public debt) and also a stationary public budget balance (or a cointegration between revenue and expenditure). In this context, and following Quintos (1995), we can also talk about "strong sustainability".

\section{EMPIRICAL RESULTS}

In order to empirically test the sustainability of the OECD area public finances in the period 1973-2016, the following variables were chosen (expressed in the form of annual time series data): debt to GDP ratio $\left(b_{t}\right)$, public expenditure as a percentage of GDP $\left(g g_{t}\right)$, revenue as a percentage of GDP $\left(\rho_{t}\right)$ and the public budget balance as a percentage of GDP $\left(s_{t}\right)$.

Before performing the tests, it is customary to analyse the behaviour of the variables graphically. Taking into account Figures 1 and 2 presented in Section 1.1, we may suspect that with the most probable exclusion of the public debt (as a percentage of GDP), there is the possibility of the remaining variables being stationary in levels, $\mathrm{I}(0)$.

To confirm this perception, the most commonly used unit root and stationary tests are chosen: the ADF (Dickey \& Fuller, 1979) and the PP (Phillips \& Perron, $1988)$, which take as their null hypothesis $\left(h_{0}\right)$ that there is a unit root. Also, the KPSS test (Kwiatkowski et al., 1992) is selected, which takes as its null hypothesis $\left(h_{0}\right)$ that there is stationarity.

The conclusions of tests for all the variables under consideration are presented in Table 3.

The intersection of the results allows us to conclude that the debt ratio as a percentage of GDP is stationary in first differences, I(1); only the KPSS test showed a different result.

Table 3. Conclusions of the stationary tests

\begin{tabular}{|l|c|c|c|c|}
\hline \multicolumn{1}{|c|}{ Variable } & ADF & PP & KPSS & Overall conclusions \\
\hline$b_{t}$ & $\mathrm{I}(1)$ & $\mathrm{I}(1)$ & $\mathrm{I}(0)$ & $\mathrm{I}(1)$ \\
\hline$\rho_{t}$ & $\mathrm{I}(1)$ & $\mathrm{I}(0)$ & $\mathrm{I}(0)$ & $\mathrm{I}(0)$ \\
\hline$g g_{t}$ & $\mathrm{I}(0)$ & $\mathrm{I}(0)$ & $\mathrm{I}(0)$ & $\mathrm{I}(0)$ \\
\hline$s_{t}$ & $\mathrm{I}(0)$ & $\mathrm{I}(0)$ & $\mathrm{I}(0)$ & $\mathrm{I}(0)$ \\
\hline
\end{tabular}

Note: for more details about these results, see Tables A2, A3 and A4 in the Appendix. 
On the other hand, the combination of the results of tests on the expenditure and revenue ratio tells us that both variables are stationary in levels, $\mathrm{I}(0)^{6}$; in the case of revenue, only the ADF tests showed another result. As far as the public budget balance is concerned, all the tests present $\mathrm{I}(0)$ as their result.

According to the literature, these results allow us to conclude that the necessary and sufficient condition for sustainability is met. This means that, when evaluating the OECD economy as a whole, its public finances were strongly sustainable over the 1973-2016 period.

In addition to the standard unit root tests, it is also possible to perform tests allowing for a structural break ${ }^{7}$. These are modified ADF tests and present as their null hypothesis $\left(h_{0}\right)$ the presence of a unit root with a possible break. The breakpoint is determined by finding the minimum value for the DF statistic in the residuals. However, there are different tests that can be performed, based on four alternative models:

1) Non-trending data with intercept break (Model 0) - tests a random walk against a stationary model with intercept break;

2) Trending data with intercept break (Model 1) - tests a random walk with drift against a trend stationary model with intercept break;

3) Trending data with intercept break and trend break (Model 2) - tests a random walk with drift against a trend stationary model with intercept and trend break;

4) Trending data with trend break (Model 3) - tests a random walk with drift against a trend stationary model with trend break.

These tests can also be performed in a sequential manner (by starting with Model 0 and stopping at the model that presents evidence of stationarity). The conclusions of this process in relation to our variables are presented in Table 4.

Table 4. Conclusions of the unit root tests with breakpoints

\begin{tabular}{|c|l|l|l|l|}
\hline Test & Model 0 & Model 1 & Model 2 & Model 3 \\
\hline $\begin{array}{c}b_{t} \\
\text { (break: 2007) }\end{array}$ & $\mathrm{I}(1)$ & $\mathrm{I}(0)$ & & \\
\hline $\begin{array}{c}\rho_{t} \\
\text { (break: 2001) }\end{array}$ & & & & \\
\hline $\begin{array}{c}g g_{t} \\
\text { (break: 2009) }\end{array}$ & $\mathrm{I}(1)$ & & & \\
\hline $\begin{array}{c}s_{t} \\
\text { (break: 2007) }\end{array}$ & $\mathrm{I}(0)$ & & & \\
\hline
\end{tabular}

Note: For more details about these results, see Table A5 in the Appendix.

\footnotetext{
${ }^{6}$ If revenues and expenditure are $\mathrm{I}(0)$, this means sustainability. For obvious reasons, it does not make sense to perform cointegration tests.

${ }^{7}$ Perron (1989) pointed out that, in certain cases, a trend-stationary process with a break could be almost observationally equivalent to unit root processes. In such cases, the standard tests may lead to the conclusion of the presence of a "false" unit root when there is, in fact, a trend-stationary process with a structural break.
} 
Comparing these conclusions with the ones that were obtained with the standard stationary tests, it can be seen that there is a divergence with respect to $g g_{t}$ which now appears to be I(1), i.e. with a different order of integration to $\rho_{t}$, which, in turn, is now trend-stationary in the presence of a structural break. On the other hand, as $s_{t}$ remains as $\mathrm{I}(0)$ and $b_{t}$ as $\mathrm{I}(1)$ in the presence of a structural break in the year 2007, there is enough evidence to confirm that the necessary (stationary public budget balance) and sufficient (stationary public debt ratio) conditions continue to be met (despite the unfavourable results regarding revenue and expenditure).

Therefore, in the presence of a structural break, we may also conclude that the public finances of the OECD area were sustainable over the 1973-2016 period ${ }^{8}$.

\section{CONCLUSION}

The public finances in the OECD area as a whole were strongly sustainable during the most recent period of the world economy, 1973-2016.

This empirical statement is based on the results obtained with different stationarity tests. Firstly, the ADF, PP and KPSS tests showed a stationary public budget balance as a percentage of GDP, a stationary public revenue and expenditure as a percentage of GDP, and also a debt to GDP ratio that was stationary in first differences. This set of results represents a "necessary and sufficient" condition for "strong sustainability". Secondly, the stationarity tests, which allow for a structural break, also showed a stationary public budget balance as a percentage of GDP and a debt to GDP ratio that was similarly stationary in first differences. This means that the "necessary and sufficient" conditions for fiscal sustainability are also robust in the presence of a structural break in data.

The conclusion on the strong sustainable public finances over the period 19732016 is especially interesting if we take into account the problems in the world economy that marked this period and seriously affected the OECD countries, such as two oil shocks, and an international financial crisis already in the present century (the most severe since the Great Depression).

We hope that this research may make an important contribution to the debate regarding public finances in the world economy. The results presented do not, however, signify that there has been individual sustainability in all of the OECD member countries. Thus, it is our intention to perform additional tests (namely stationarity tests) in the near future, in order to assess which members are contributing to the fiscal sustainability of the OECD aggregate and which ones are not.

\footnotetext{
${ }^{8}$ The results of our paper point to sustainability when all the thirty-five member countries are as if they were one body. As far as conclusions from other research studies are concerned, we draw attention to Afonso and Jalles (2012). The authors tested the sustainability of public finances in a sample of OECD member countries in the period 1970-2010. Their results showed an "absence of sustainability - between government revenues and expenditures for most countries (except for Austria, Canada, France, Germany, Japan, Netherlands, Sweden, and the UK)" and also the "nonstationarity of the first-differenced debt series for most countries (with the exception of Australia, Germany, Greece and the UK with the ADF and PP tests (...)”.'.
} 


\section{ACKNOWLEDGMENT}

The author would like to thank the two anonymous referees for their helpful comments and recommendations.

\section{REFERENCES}

Afonso, A., \& Jalles J. (2012). Revisiting fiscal sustainability - Panel cointegration and structural breaks in OECD countries. European Central Bank - Working Paper Series, 1465. https://doi.org/10.2139/ssrn.2180575

AMECO. (2017). Annual Data on Public Finances. Retrieved May 24, 2017, from AMECO database, http://ec.europa.eu/economy_finance/ameco/ .

Black, S. (1985). Learning from adversity: policy responses to two oil shocks. Essays in International Finance, 160, 1-24. $\quad$ Retrieved from https://www.princeton.edu/ ies/IES_Essays/E160.pdf

Blanchard, O., Chouraqui J., Hagemann R., \& Sartor, N. (1990). The sustainability of Fiscal Policy: New Answers to an Old Question. OECD Journal: Economic Studies, 15, 7-36. Retrieved from http://www.oecd.org/eco/outlook/34288870.pdf

BP (2016). Annual Crude Oil Prices. Retrieved April 20, 2017, from British Petroleum database, http://www.bp.com/en/global/corporate/energy-economics/statistical-review-of-world-energy/ .

Chabert, G., \& Clavel, L. (2012). Lessons for today from Sweden's crisis in the 1990s. Ministère de l'Economie, et des Finances et Ministère du Commerce Extérieur, Trésor-Economics, 105. Retrieved from https://www.tresor.economie.gouv.fr/Ressources/File/377309

Chalk, N., \& Hemming R. (2000). Assessing Fiscal Sustainability in Theory and Practice. International Monetary Fund (IMF), Working Paper, WP/00/81, 1-27. https://doi.org/10.2139/ssrn.2109394

Dickey, D., \& Fuller W. (1979). Distribution of the estimators for time series regressions with a unit root. Journal of the American Statistical Association, 74(366), 427-431. https://doi.org/10.2307/2286348

European Central Bank. (2011). Ensuring fiscal sustainability in the Euro Area, ECB Monthly Bulletin, April Newsletter, 61-77. European Central Bank. Retrieved from https://www.ecb.europa.eu/pub/pdf/other/art1_mb201104en_pp6177en.pdf?7e60e35118a9713b28501fa1819b9880

European Commission. (2008). Communication from the Commission to the European Council - A European Recovery Plan, COM (2008) 800 final. European Commission. Retrieved from http://ec.europa.eu/economy_finance/publications/pages/publication13504_en.pdf

European Commission. (2009). Economic Crisis in Europe: Causes, Consequences and Responses, European Economy 7|2009. European Commission. Retrieved from http://ec.europa.eu/economy_finance/publications/pages/publication15887_en.pdf

European Commission. (2016). European Semester Thematic Factsheet - Sustainability of Public Finances. European Commission. Retrieved from https://ec.europa.eu/info/sites/info/files/european-semester_thematic-factsheet_public-financesustainability_en.pdf

Eviews. (2017). Eviews 9.5 version. Retrieved from http://www.eviews.com/

Hakkio, C., \& Rush, M. (1991). Is the budget deficit 'too large'? Economic Inquiry, 29, 429-445. https://doi.org/10.1111/j.1465-7295.1991.tb00837.x

IMF (2017). World Economic Outlook (April 2017) - General government gross debt, percent of GDP. International Monetary fund. Retrieved http://www.imf.org/external/datamapper/GGXWDG_NGDP@WEO?year=2017

Jonung, L., Kiander J., \& Vartia, P. (2008). The great financial crisis in Finland and Sweden - The dynamics of boom, bust and recovery, 1985-2000. Directorate-General for Economic and Financial Affairs, European Commission, Economic Papers, 350, 1-70. Retrieved from http://ec.europa.eu/economy_finance/publications/pages/publication13551_en.pdf 
Kwiatkowski, D., Phillips. P., Schmidt P., \& Shin Y. (1992). Testing the null hypothesis of stationarity against the alternative of a unit root. Journal of Econometrics, 54, 159-178. https://doi.org/10.1016/0304-4076(92)90104-Y

Llewellyn, J. (1983). Resource prices and macroeconomic policies: Lessons from two oil price shocks. OECD Journal: Economic Studies, 1, 197-212. Retrieved from http://www.oecd.org/eco/outlook/35552323.pdf

Maddison, A. (1995). Monitoring the World Economy. Paris: OECD.

Maddison, A. (2001). The World Economy - A millennial perspective. Paris: OECD. http://doi.org/10.1787/9789264189980-en

OECD (2017). Annual Data on Public Finances. Retrieved from OECD Economic Outlook Statistics - No. 101 - June 2017. Retrieved June 9, 2017, from https://stats.oecd.org/index.aspx?DataSetCode=EO\#

Pereira, P., Afonso A., Arcanjo M., \& Santos J. (2005). Economia e finanças públicas. Lisbon: Escolar Editora.

Perron, P. (1989). The Great Crash, the Oil Price Shock, and the Unit Root Hypothesis. Econometrica, 57, 1361-1401. https://dx.doi.org/10.2307/1913712

Phillips, P.C.B., \& P. Perron (1988). Testing for a Unit Root in Time Series Regression. Biometrika, 75, 335-346. https://doi.org/10.2307/2336182

Quintos, C. (1995). Sustainability of the deficit process with structural shifts. Journal of Business \& Economic Statistics, 13, 409-417. https://doi.org/10.2307/1392386

Schwert, G. (1989). Tests for unit roots: A Monte Carlo investigation. Journal of Business \& Economic Statistics, 7, 147-159. https://doi.org/10.2307/1391432

Trehan, B., \& Walsh C. (1991). Testing intertemporal budget constraints: theory and applications to U.S. federal budget and current account deficits. Journal of Money, Credit and Banking, 23, 206-223. https://doi.org/10.2307/1992777

World Bank (2017). Annual Data on GDP. Retrieved from World Bank database. Retrieved April 29, 2017, from http://data.worldbank.org/indicator/NY.GDP.MKTP.KD

\section{AUTHORS' SHORT BIOGRAPHY}

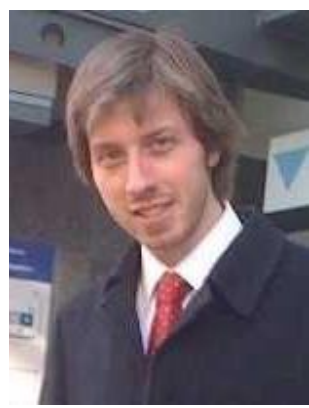

Ricardo Ferraz received his $\mathrm{PhD}$ degree in Economics and Social History from the Lisbon School of Economics \& Management, University of Lisbon (ISEG), and subsequently completed a post-doctoral research project at the Social and Economic History Research Unit (GHES) run by the $C S G$ consortium of ISEG. The author is a Visiting Professor at the Coimbra Institute of Engineering (ISEC), a Researcher at GHES/CSG and an Economics Advisor at the Portuguese Parliament. 


\section{APPENDIX}

Table A1. Public debt data sources

\begin{tabular}{|c|c|c|}
\hline Country & Period & Source \\
\hline Australia & 1989-2016 & $\operatorname{IMF}(2017)$ \\
\hline Austria & $1973-2016$ & \multirow{2}{*}{ AMECO (2017) } \\
\hline Belgium & 1973-2016 & \\
\hline Canada & 1980-2016 & \multirow{2}{*}{ IMF (2017) } \\
\hline Chile & 1990-2016 & \\
\hline Czech Republic & 1995-2016 & \multirow{8}{*}{ AMECO (2017) } \\
\hline Denmark & 1973-2016 & \\
\hline Estonia & 1995-2016 & \\
\hline Finland & 1973-2016 & \\
\hline France & 1977-2016 & \\
\hline Germany & 1973-2016 & \\
\hline Greece & 1973-2016 & \\
\hline Hungary & 1995-2016 & \\
\hline Iceland & 1982-2016 & IMF (2017) \\
\hline Ireland & 1973-2016 & AMECO (2017) \\
\hline Israel & 2000-2016 & IMF (2017) \\
\hline Italy & 1973-2016 & \multirow{2}{*}{ AMECO (2017) } \\
\hline Japan & $1973-2016$ & \\
\hline Korea & 1990-2016 & IMF (2017) \\
\hline Latvia & 1995-2016 & \multirow{2}{*}{ AMECO (2017) } \\
\hline Luxembourg & 1973-2016 & \\
\hline Mexico & 1996-2016 & IMF (2017) \\
\hline Netherlands & 1975-2016 & AMECO (2017) \\
\hline New Zealand & 1985-2016 & \multirow{2}{*}{ IMF (2017) } \\
\hline Norway & 1980-2016 & \\
\hline Poland & 1995-2016 & \multirow{6}{*}{ AMECO (2017) } \\
\hline Portugal & 1973-2016 & \\
\hline Slovak Republic & 1995-2016 & \\
\hline Slovenia & 1995-2016 & \\
\hline Spain & 1973-2016 & \\
\hline Sweden & 1973-2016 & \\
\hline Switzerland & 1973-2016 & IMF (2017) \\
\hline Turkey & 2000-2016 & \multirow{3}{*}{ AMECO (2017) } \\
\hline United Kingdom & 1973-2016 & \\
\hline United States & 1973-2016 & \\
\hline
\end{tabular}


Table A2. ADF Results

\begin{tabular}{|l|l|l|l|}
\hline \multicolumn{5}{|l|}{ Test with constant and without trend } \\
\hline Variable & Lags & Test Statistic & Conclusion \\
\hline$b_{t}$ & 1 & -1.97 & Non-stationary \\
\hline$\rho_{t}$ & 1 & -2.16 & Non-stationary \\
\hline$g g_{t}$ & 1 & $-3.35^{* *}$ & Stationary \\
\hline$s_{t}$ & 1 & $-4.01^{* * *}$ & Stationary \\
\hline Test with constant and trend \\
\hline Variable & \multicolumn{1}{|l}{ Lags } & Test Statistic & Conclusion \\
\hline$b_{t}$ & 1 & -2.83 & Non-stationary \\
\hline$\rho_{t}$ & 1 & -2.34 & Non-stationary \\
\hline Test with constant and without trend \\
\hline Variable & Lags & Test Statistic & Conclusion \\
\hline$\Delta b_{t}$ & 1 & $-3.73^{* * *}$ & Stationary \\
\hline$\Delta p_{t}$ & 2 & $-4.96^{* * *}$ & Stationary \\
\hline
\end{tabular}

Source: Own calculations using Eviews (2017).

Note 1: *,** and *** denote rejection of the null hypothesis $\left(h_{0}\right)$ of a unit root at the $10 \%, 5 \%$ and $1 \%$ levels.

Note 2: the maximum lag was chosen using the rule provided by Schwert (1989). The actual lag was obtained automatically by Eviews (2017) using the Schwarz Info Criterion (SIC).

Table A3. PP Results

\begin{tabular}{|l|l|l|l|}
\hline \multicolumn{4}{|l|}{ Test with constant and without trend } \\
\hline Variable & Lags & Test Statistic & Conclusion \\
\hline$b_{t}$ & 3 & -1.36 & Non-stationary \\
\hline$\rho_{t}$ & 6 & $-2.90^{*}$ & Stationary \\
\hline$g g_{t}$ & 0 & $-3.43^{* *}$ & Stationary \\
\hline$s_{t}$ & 2 & $-3.12^{* *}$ & Stationary \\
\hline Test with constant and trend & \\
\hline Variable & Lags & Test Statistic & Conclusion \\
\hline$b_{t}$ & 3 & -1.90 & Non-stationary \\
\hline Test with constant and without trend \\
\hline Variable & Lags & Test Statistic & Conclusion \\
\hline$\Delta b_{t}$ & 2 & $-3.34^{* *}$ & Stationary \\
\hline
\end{tabular}

Source: Own calculations using Eviews (2017).

Note 1: *,** and *** denote rejection of the null hypothesis $\left(h_{0}\right)$ of a unit root at the $10 \%, 5 \%$ and $1 \%$ levels.

Note 2: the actual lag was obtained automatically by Eviews (2017) using the New-West automatic selection of bandwidth. 
Table A4. KPSS Results

\begin{tabular}{|l|l|l|l|}
\hline \multicolumn{4}{|l|}{ Test with constant and without trend } \\
\hline Variable & Lags & Test Statistic & Conclusion \\
\hline$b_{t}$ & 5 & $0.64^{*}$ & Stationary \\
\hline$\rho_{t}$ & 5 & $0.56^{* *}$ & Stationary \\
\hline$g g_{t}$ & 4 & $0.41^{*}$ & Stationary \\
\hline$s_{t}$ & 3 & 0.08 & Stationary \\
\hline
\end{tabular}

Source: Own calculations using Eviews (2017).

Note 1: *,** and *** denote rejection of the null hypothesis $\left(h_{0}\right)$ of stationarity at the $10 \%, 5 \%$ and $1 \%$ levels.

Note 2: the actual lag was obtained automatically by Eviews (2017) using the New-West automatic selection of bandwidth.

Table A5. Unit root test with a breakpoint

\begin{tabular}{|c|c|c|c|c|}
\hline \multicolumn{5}{|c|}{ Non-trending data with intercept break } \\
\hline Variable & Lags & Break & Test Statistic & Conclusion \\
\hline$b_{t}$ & 1 & 2007 & -4.13 & Non-stationary \\
\hline$\rho_{t}$ & 0 & 1979 & -3.22 & Non-stationary \\
\hline$g g_{t}$ & 1 & 2007 & -4.10 & Non-stationary \\
\hline$s_{t}$ & 1 & 2007 & $-4.50 * *$ & Stationary \\
\hline \multicolumn{5}{|c|}{ Trending data with intercept break } \\
\hline Variable & Lags & Break & Test Statistic & Conclusion \\
\hline$b_{t}$ & 1 & 1993 & -4.35 & Non-stationary \\
\hline$\rho_{t}$ & 4 & 2001 & $-5.55 * * *$ & Stationary \\
\hline$g g_{t}$ & 1 & 1995 & -4.53 & Non-stationary \\
\hline \multicolumn{5}{|c|}{ Trending data with intercept and trend break } \\
\hline Variable & Lags & Break & Test Statistic & Conclusion \\
\hline$b_{t}$ & 1 & 1994 & -3.93 & Non-stationary \\
\hline$g g_{t}$ & 1 & 1995 & -4.36 & Non-stationary \\
\hline \multicolumn{5}{|c|}{ Trending data with trend break } \\
\hline Variable & Lags & Break & Test Statistic & Conclusion \\
\hline$b_{t}$ & 1 & 2007 & -3.07 & Non-stationary \\
\hline$g g_{t}$ & 1 & 1985 & -3.56 & Non-stationary \\
\hline \multicolumn{5}{|c|}{ Non-trending data with intercept break } \\
\hline Variable & Lags & Break & Test Statistic & Conclusion \\
\hline$\Delta b_{t}$ & 1 & 2007 & $-4.27 *$ & Stationary \\
\hline$\Delta g g_{t}$ & 0 & 2009 & $-6.31 * * *$ & Stationary \\
\hline
\end{tabular}

Source: Own calculations using Eviews (2017).

Note 1: $* * *$ and $* * *$ denote rejection of the null hypothesis $\left(h_{0}\right)$ of a unit root at the $10 \%, 5 \%$ and $1 \%$ levels.

Note 2: the maximum lag was chosen using the rule provided by Schwert (1989). The actual lag was obtained automatically by Eviews (2016) based on the Schwarz Info Criterion (SIC). 